\title{
'KEEPING THE PEACE'
}

\section{Social Identity, Procedural Justice and the Policing of Football Crowds}

\author{
Clifford Stote*, James Hoggett and Geoff Pearson
}

This paper explores the relevance of the Elaborated Social Identity Model of Crowd Behaviour and Procedural Justice Theory to an understanding of both the presence and absence of collective conflict during football (soccer) crowd events. It provides an analysis of data gathered during longitudinal ethnographic study of fans of Cardiff City Football Club-a group of supporters with a notorious history of involvement in 'hooliganism' within the English domestic Football Leagues. The analysis suggests that the perceived legitimacy among fans of the way they were policed affected the internal dynamics, patterns of collective action and overall levels of 'compliance' among the fan group. On this basis, we contend that these processes mediated both a long-term decline but also the sporadic reemergence of collective conflict during crowd events involving the fans. The paper concludes by exploring the implications of our analysis for informing policy, practice and theory, particularly with respect to the importance of policing with consent as a route to conflict reduction in domestic football.

Keywords: hooliganism, public order, policing, crowds, procedural justice, consent, disorder, social identity

\section{Introduction: The Dynamics of Football Crowds}

The issue of football 'hooliganism' has historically been the focus of a relatively polarized debate within the social sciences (see Frosdick and Marsh (2005) for an overview). In recent years, these debates have been superseded through a series of studies of collective conflict involving English fans travelling abroad to major international football tournaments. That research has highlighted the explanatory power of analysing such events from the perspective of the Elaborated Social Identity Model of crowd behaviour (Drury and Reicher 2000; Reicher 1996; Stott and Drury 2000). Of particular importance is that this research demonstrates the determining role played by public order policing in shaping the social and psychological dynamics of the football crowd events. These dynamics, in turn, determine whether collective conflict does or does not emerge (Stott and Reicher 1998b; Stott et al. 2001; 2007; 2008a; Stott and Schreiber in press; Stott and Pearson 2007).

For example, Stott and Reicher (1998b) argue that the relatively indiscriminate and inappropriate use of force against England fans by Italian police during the 1990 World Cup created a social context that united 'hooligans' and 'ordinary fans' around a common understanding of 'victimhood'. In theoretical terms, the context created by police action led directly to the emergence of a 'social identity' among fans, defined in terms of

* Department of Applied Psychology, University of Liverpool, Eleanor Rathbone Building, Bedford Street South, Liverpool, L69 7ZA, UK; c.stott@liverpool.ac.uk. 
the illegitimacy of their intergroup relationships with the police. This social identity then fed an emergent norm among fans based around the perceived legitimacy of 'retaliation' against the police. Moreover, the psychological unity of this identity empowered fans, ensuring that retaliation against the police was not only seen as proper, but also possible, social action. Such collective action then precipitated an upward spiral of conflict that culminated in what was defined by the mass media as a 'riot'.

During the 2004 European Championships in Portugal, the Polícia de Segurança Pública (PSP) based their approach to crowd management on Elaborated Social Identity Model (ESIM) principles (Reicher et al. 2004; 2007). Consequently, their strategy was designed to maximize perceptions of police legitimacy in the use of discretionary force during crowd events. The PSP therefore gave a strategic priority to facilitating fans' enjoyment alongside a tactical commitment to dialogue with fans, over and above the more usual prioritization of deterrence and control. Correspondingly, evidence derived from the tournament suggests that, in this context, fans perceived their intergroup relationships with the police as legitimate. Moreover, while there were no major incidents in areas under the jurisdiction of the PSP, evidence further suggests that the low levels of 'hooliganism' were linked to an emergent 'self-regulation' culture among 'high-risk' fan groups (Schreiber and Stott in press; Stott et al. 2007; 2008a).

The ESIM focus upon police use of force, perceived legitimacy and consequential 'self-regulation' in crowds mirrors in many respects the model of 'process-based regulation' proposed by 'procedural justice theory' (PJT; Tyler 1990; 2003; 2007; Tyler and Huo 2002). PJT is based upon assumptions of 'normative compliance' where people conform to the law because they perceive a moral, ethical and ideological obligation to do so (Tyler 1990; Hough 2007). PJT theorists suggest that 'criminality' can be reduced where powerful groups such as the police use discretionary force in ways that are understood as 'fair' (Hough et al. 2010; Jackson et al. in press; Sunshine and Tyler 2003). This is because, where people confer 'legitimacy' on the police, they are more likely to 'trust' the authorities and to 'self-regulate' (measured in terms of concepts such as obeying the police, complying with the law and co-operation with justice).

These 'compliance' processes are, in turn, understood to be mediated psychologically by social identity and self-categorization processes (Tyler and Blader 2001; 2000; 2003). PJT and its associated 'Group Engagement Model' correspondingly share Self Categorisation Theory's conceptualization of identity as an ideologically informed judgment about the position of one's group within a social context (Turner et al. 1994). Moreover, the 'identity information' individuals receive from the group is understood to 'emanate from the evaluations of procedural fairness experienced in the group' (Tyler and Blader 2003: 353). In other words, as with the ESIM, the form and content of the identity, and therefore the level of normative 'compliance' to the law, are assumed to emanate from judgments concerning the legitimacy in the intergroup context: a context that is itself-at least in part—created by the actions of the police (Drury et al. 2003; Hoggett and Stott 2010a; 2010b; Stott 2003; Stott and Drury 2000; Stott and Reicher 1998a; cf. Blader and Tyler 2009: 447).

Nonetheless, despite the fact that PJT now has considerable empirical support (Tyler 2007) and 'is rooted in attempts to understand and explain riots and rebellion' (Tyler and Blader 2003: 351), there is actually little in the way of empirical research that explores the applicability of the approach to the management of crowds (Murray 2010). Moreover, despite the explanatory power, extensive supporting evidence and policy application of the ESIM along with the striking similarities of the model to PJT- 
particularly with respect to the drivers and function of legitimacy in police public relations - there is as yet no systematic empirical research on the applicability of ESIM to the policing of domestic football crowds (Hoggett and Stott 2010a; 2010b).

This is important because the risk of rapidly escalating disorder amongst football crowds remains of significant political and practical concern, particularly in light of current pressures to reduce public sector spending (Hansard, Commons, 18 May 2011: Col. 134WH). However, when the UK Home Office released its statistics of football-related arrests for the 2009-10 season, anyone would be forgiven for thinking that 'hooliganism' was a thing of the past. The 3,391 arrests across the season represent a decrease of 10 per cent compared with the previous season and were just 0.01 per cent of the 39 million spectators. Whilst we need to treat these figures with caution, they do portray a relatively benign environment, but behind these statistics lays a fundamental problem: the cost of policing. For example, in October 2010, the Association of Chief Police Officers estimated that, on average, it cost $£ 25$ million per year to police regulated football in England and Wales. The estimates of police costs suggest that the apparently low level of football crowd violence in England and Wales is being achieved because local police forces are managing these crowds through the heavy and expensive use of resources.

The question faced by policy makers, given the impending budgetary cuts to policing, is how these year-on-year costs of policing football can be reduced without seeing a concurrent rise in the levels of football-related 'disorder'. The problem for criminologists, therefore, is to understand if and how research and theory derived from PJT and ESIM might contribute some form of answer to this question. Reflecting Lewin's (1951) assertion that 'there is nothing so practical as a good theory' (Lewin 1951: 169), our aims in the present paper are twofold. First, we seek to address a limitation of the existing literature, by exploring the processes governing both the absence and the presence of collective conflict among fans attending fixtures within the English Football League. Second, in so doing, we aim to explore the capability of ESIM and PJT to address and inform policy for reducing policing costs in this context without seeing any major escalation in the levels of crowd disorder.

\section{Method}

\section{Data gathering}

The central method adopted in previous ESIM-based research on football-related conflict has been participant observation with the same fan group across multiple events (see Stott and Pearson 2007: 209-19; Pearson 2011; Pearson and Sale 2011). This approach offers the flexibility necessary to directly observe collective action and to build the relationships of trust with key actors and groups that are necessary to gather meaningful data from situations in which groups are embedded in entrenched intergroup conflicts (see Burgess 1982; Drury and Stott 2001; Hammersley and Atkinson 1983; Whyte 1994). This approach also has the advantage of allowing for qualitative comparisons across different contexts, both in terms of 'objective' features and in terms of participant phenomenology.

\section{Cardiff City Football Club}

The reputation of fans of Cardiff City Football Club (CCFC) for collective violence has developed as a result of a series of major incidents of intergroup conflict across many years 
(e.g. Davies 2009). Throughout the 1980s and 90s, 'hooliganism' at football became highly publicized and, within this framework, CCFC's 'Soul Crew', the name adopted by the club's 'hooligan' following, are widely considered one of the main protagonists. Home Office figures in the season 2009-10 show that 125 CCFC fans hold Football Banning Orders (FBOs) (James and Pearson 2006; Stott and Pearson 2006), which prevent them from attending any matches in the Football League, second only in number to Leeds United. Of the 117 CCFC fans arrested that season, 85 were arrested for violent or public order-related offences and 109 of them were made at away fixtures. Their notoriety and centrality to the phenomena of 'hooliganism' make this fan group an ideal candidate for systematically addressing factors underlying the presence and absence of major incidents of collective conflict. To address the research questions, we therefore present analyses of data gathered from a three-year participant observational study of relations between fans of CCFC, police and other fan groups across multiple events and locations.

A key aim of the approach was to gain access to, and gather data from, the relevant interacting groups. Subsequently, the first and second author conducted a series of semi-structured observations at $23 \mathrm{CCFC}$ fixtures where access was available to the host police force or invitations were forthcoming from CCFC or CCFC fan groups. Where access to the host police force was available, it was possible to attend police briefings, view police strategic and tactical documentation and take an overview of the police operation throughout. Where access to the host force was not sought or available, access to matches was provided by CCFC. These observations took the form of participating in the event either among Cardiff City fans or accompanying the CCFC safety and security team. Observations record the approximate chronology of events and the observers' qualitative impressions of fan behaviour, fan group interactions, police deployment (numbers, uniform, behaviour, etc.), fan and police interactions and any other aspects of the situation judged at the time by the observers to be theoretically relevant. These data were recorded onto audio recorders and later transcribed. Photographs and video were also used to record events when this was possible. For some fixtures, pre-event planning meetings were attended, and pre- and post-event interviews conducted. Throughout each fixture, semi-structured interviews with various parties took place (e.g. police at all levels, club officials, fans, etc.). On these occasions, interviews were guided by specific theoretical concerns as relevant to the (often rapidly developing) surrounding events and the data were recorded contemporaneously. All key actors were fully aware of our research intentions and provided informed consent prior to their first interview.

Between January 2005 and April 2008, the first author was in regular communication with the South Wales Police (SWP) Operational Command team, CCFC Safety and Security Team and SWP. These communications generally focused upon the strategy and tactical approaches to the management of Cardiff fans, their relationships to other police forces, the nature of the threat to public order posed by Cardiff fan groups and details regarding the levels of resources, arrests and FBOs. Access was also provided to key policy documents and statements made by fans to the club regarding their treatment by police. Additionally, a series of meetings, interviews and other communications took place with key representatives from the Cardiff fan base, including individuals known to the police as prominent 'hooligans'. In general terms, these focused upon fans' intentions, their experiences of policing, relationships with other fans groups, their views upon violence and those involved in it and relationships to other agencies such as CCFC and SWP. Data were recorded contemporaneously or subsequently as audio or written field notes. 


\section{Analytical strategy}

The analysis began by triangulating the observational, interview and documentary data to establish consensual accounts of the various events (cf. Denzin 1989). Unless otherwise stated, the account of events presented here is based upon either (1) direct evidence from official statistic, direct observation, video or photographic evidence, or (2) agreement between two or more independent sources of data (e.g. between independent interview data). Where sources diverged or only one provides data, a specific reference to that source is given prior to a description of the event. The examples provided are indicative of the general issues identified across multiple events. The one exception is the incident of major 'disorder' at Wolverhampton FC, which was the only major incident involving fans of CCFC within the sample of fixtures directly observed by the authors.

Fan interview data were then thematically organized using a constructionist revision of grounded theory (Smith and Osborn 2003; Glaser and Strauss 1967) in order to explore how events corresponded with descriptions of fans' social identity and relationship to others. This data were then cross-referenced with police interview data and statistics to explore how the events, social and psychological processes evident among fans and police understandings, strategy and tactics corresponded. The extracts from the qualitative data presented were selected for their representativeness within the relevant thematic category. The suffix indicates the precise origin of the extract.

\section{Analysis}

In May 2001 and January 2002, there were two serious and high-profile incidents of 'rioting' involving hundreds of Cardiff fans. Following these incidents, the SWP, CCFC, Cardiff fans and the local authority began to develop initiatives to address what they saw as the underlying causes of the conflicts. Our data suggest that a series of changes flowed from this initiative.

According to statistical evidence, there was a subsequent steep decline in the levels of intergroup conflict involving CCFC fans, reflected in the number of CCFC fans arrested and the amount of resources used to police matches at Ninian Park (then CCFC's stadium) between 2002 and 2006. For example, in the season 2002/03, there were 194 Cardiff fans arrested (both home and away) but, by 2004/05, this figure had declined by over 50 per cent to 90 . Correspondingly, the SWP recorded 14 'significant incidents' of disorder involving CCFC fans during the 2002/03 season, which, by 2004/05, had declined to a total of five, none of which occurred at Ninian Park. Furthermore, according to the SWP, only three of these involved what they describe as 'major disorder'. This reduction in the number of incidents was reflected in the scale of policing operations at Ninian Park, where the 2001/02 season saw the use of approximately 1,716 police officers. By 2005/06, this had declined by approximately 50 per cent to 946 officers.

One prominent feature of 'anti-disorder' initiatives in UK domestic football has been the implementation of FBOs, whereby a large number of Cardiff fans were prevented from attending matches. In 2002, CCFC had the highest number of arrests and football banning orders of any club in England and Wales. However, the removal of hooligans from the fan base represents an insufficient explanation for these changing patterns of disorder because of the continued sporadic emergence of conflict at CCFC fixtures between 2002 and 2005, notably all at matches away from Ninian Park. 
STOTT ET AL.

This overall pattern raises two crucial, related questions: what processes determined the apparent decline in conflict involving Cardiff fans, particularly at home fixtures? Moreover, how can the processes underpinning the absence of conflict at the majority of away fixtures account for its sporadic re-emergence at others?

\section{Fan group identity and social influence}

Being one of the largest football clubs in Wales, CCFC has traditionally drawn a large contingent of fans from the three major valleys just north of the city. Partially due to the area's poor national rail links, groups of CCFC fans from the different towns and villages often travel to away fixtures by private hire coaches, mini-bus or cars. By late 2001, the different groups throughout the valleys had begun to coalesce into a single coach-based travel club. This relatively informal organization went under the banner of the "Valley RAMs' (i.e. the Valleys of the Rhondda, Aberdare and Merthyr).

Over the following year, the RAMs rapidly expanded, for some 'away' fixtures organizing up to 30 coaches containing approximately 1,500 fans (see Davies 2009). Our data suggest that a central feature of the RAM's identity was a desire to utilize supporting CCFC as an escape from the tensions of everyday life. For them, going to watch CCFC was not just about watching football, but an opportunity for drunken boisterous communal revelry, explicitly differentiated from-but sometimes involving-active 'hooliganism':

People like to drink or have a bag of chips, bet on the horses, have a sing-song, find a pub, go to the game, sing their head off, make a fool of themselves, let their hair down, and come home. It doesn't mean that they're hooligans; that they want to fight. (Fan, VR)

RAMs we interviewed also emphasized the importance of a cultural norm of solidarity, particularly in situations of intergroup conflict:

You wouldn't get on the bus and leave your mate outside if the police were heavy handed and pushing because you would be seen as a coward, you would stay there with you mate because there's a threat. (Fan, VR)

Our data suggest that this commitment to defending each other was a key feature of why RAMs sometimes became actively involved in the incidents of 'disorder' recorded in the official police statistics. Moreover, our data also suggest that the fighting power of Cardiff's active 'hooligans' - the 'Soul Crew' — was mediated primarily by their ability to influence the spontaneous involvement of large contingents of the RAMs. As one of the South Wales Police football intelligence team commented:

For me the Soul Crew were nothing without the Valleys behind them because the Valley Boys [RAMs], they are big hard boys and they have got the numbers. The Soul Crew would say 'oh we have got to fight

them, there is fifty of us, come on lads' and then they would have two thousand of the Valley boys charging behind them and it looks impressive. (SWP FIO, SI)

\section{Reducing conflict: legitimacy and a changing social context}

Our interviews with officers from the SWP suggested that, following the 'riots' of 2001/ 02, the SWP came to reflect upon the limitations of their approach to policing public 
order. As a senior Commander at Ninian Park during this period commented: 'What we were doing was a real failure in policing' (SWP Chief Supt., 01).

By way of a solution, the SWP took an active role in establishing a new approach to the problem based not on 'deterrence', but upon 'dialogue'. As a first step towards this, they organized a series of meetings with the various relevant groups, including CCFC, the local authority and influential representatives from the RAMs. The feedback obtained by SWP from fans at these meetings led directly to changes in police tactics where they moved away from overt displays of their capability to use force. This 'dialogue-based' approach was seen by some as leading directly to an emergent sense of police legitimacy among fans. As a CCFC official pointed out:

There was no contact, no dialogue, there was nothing. Then they [the police] stopped that. They started talking to fans and ... the [police] would interact with the fans, go to the fans meetings, the fans then thought 'we know why they [the police] are here now they are not here to beat us up, there not here to bludgeon us, there here for a reason', and the fans reacted accordingly. (Club Official AK, 1)

Our interview data suggest that, prior to these changes, many fans had understood their relationship with the club, SWP and the authorities more generally in terms of illegitimacy and antagonism. In this context, RAMs described how they saw it as acceptable to engage in aggressive acts without fear of censure from other supporters:

It was a case of in the past, fuck the club. You know what have they done for us. We were seen as the enemy here, let's do what we want. If you want to snap something on the way out, you'd snap something, no one [other fans] would say anything. (Fan, DK)

However, after the new approach was implemented, RAMs described a sense of cooperation and identification with the club. Some RAMs spoke explicitly of a new relationship between fans and the SWP, defined in terms of mutual respect and legitimacy:

There are bridges built with the police in Cardiff, definitely, and we've got respect. We know a lot of good, some good police in Cardiff who have got respect for the boys. They are fair they won't let you break the law or whatever, but they'll treat you fair. (Fan, KT)

In this context of intergroup legitimacy, RAMs described how their 'hooligan' contingent lost influence:

We still got some [fans] who don't want to improve, but they have been isolated because the majority of the bad guys you know as a percentage, take one hundred of the bad guys, you've got five raving right wing lunatics, five up the other end who don't want nothing, and a massive amount in the middle who get caught up in things. Well those five out of the hundred, the nutters who want to fight all the time and don't care what they do to the club, will try and kick things off and arrange things when they know they've got 95 behind them, now those 95 will say fuck off. (Fan, GD)

RAMs also described episodes of 'self-regulation' during crowd events. For example, an influential figure within the RAMs described an incident when he used violence in order to protect club stewards and prevent an attack on opposition fans following a tense local derby:

I tried to reason with the lads [other Cardiff fans] at the front. I was shouting 'look boys you're not going to get anywhere near the Bristol [opposition] fans' .... Some of the older heads [experienced 
STOTT ET AL.

Cardiff fans] mixed amongst them, knew me and knew where I was coming from, but suddenly this one lad fronted me ... so I just gave him a good slap .... Whilst all this was happening a couple of Valley Rams and other [Cardiff] City fans that knew me, had come forward to back me up. (Fan, GD)

SWP Commanders described how the new approach also led to an improvement in the quantity and quality of the intelligence they were able to gather concerning the movement and intentions of 'hooligans'. As one of Cardiff's most notorious 'hooligans' noted, even he would wilfully communicate relevant and valid information to the SWP concerning his whereabouts on match days. He is explicit that such communication is linked directly to the sense of legitimacy he now saw in the SWP's approach to the policing of football:

They [the SWP] ring me ask me where we are, I don't lie, I don't tell them no lies you know what I mean, and I class them as decent people, and I class South Wales Police right, not in every walk of life like, but as regards of football they are the model every other police force should look at. (Fan, KT)

Police commanders in the SWP considered that the improved intelligence allowed them to generate more confidence in the validity of their judgments concerning the risks posed by specific fixtures. In particular, if the police intelligence teams had found no evidence of a potential for 'disorder', commanders would not see this as a failure of intelligence, but as an accurate reflection that 'disorder' was not likely. As a consequence, instead of deploying large numbers of police as a contingency, they would develop the necessary confidence to police such events with smaller numbers of police. As a SWP commander noted:

One of the most critical things for me is trusting your intelligence. If [the $\mathrm{FIO}^{1}$ ] comes to me and says 'there's no problem with this, we need a Sergeant and twelve' [PC's], then that's what we will police it with and if he says 'we need five PSUs ${ }^{[2]}$, that's what we will police it with. Its trusting that intelligence and I think we've got it right time after time. (SWP, Supt, 02)

Therefore, the dialogue approach appears to have had direct benefits because it allowed SWP to improve their capability for assessing 'risk' to public order, which, in turn, allowed the necessary confidence to reduce the overall numbers of police deployed at these operations. Indeed, as another SWP senior commander commented:

This time four years ago, we'd have been policing this game with what, 6-8 PSUs and here we are doing it with three tomorrow. It [the dialogue approach] is a win win, the club are saving money because they are not paying for the same number of officers at games and we're saving, with the overall wider community of South Wales also benefiting as there's less officers being subtracted from their communities to police the football. What I can't understand is why my colleagues around the country are perhaps not taking the same view. (SWP, C. Supt, 01)

\section{Policing at matches away from home}

The stadium manager, club safety officer and SWP sought to minimize the risk their fans posed to public order not just at home, but also at away fixtures. Such events invariably

\footnotetext{
${ }^{1}$ Football Intelligence Officer, a police officer with the specific role of gathering intelligence for use in securing prosecutions and FBOs.

${ }^{2} \mathrm{PSU}$ is the acronym for police support unit, which is a public-order-trained police unit consisting of three police serials (one sergeant and six PCs per serial) and one inspector.
} 
fall under the jurisdiction of other police forces over which the SWP have little, if any, influence. One of the strategies adopted by CCFC and SWP was to organize meetings with the host club and police force prior to the fixture in order to exchange information, develop cooperation, discuss and try to agree strategies and tactics. Often central to such discussions was the issue of alcohol consumption.

Consuming alcohol is a central aspect of the RAMs culture and identity but drinking alcohol on a coach going to a football league fixture in England and Wales is an offence under the Sporting Events Act 1985. CCFC 'official' coaches would therefore not allow fans to consume alcohol on board. However, RAMs organizers described how many, particularly those fans seen as posing a risk to public order, would not be willing to travel on any coach where alcohol was prohibited:

If I say to them no you can't have a drink on the bus they will do their own thing. If I say 'look boys this is a dry trip' they won't come, because [drinking] it's such a big part of it. (Fan, CK)

Nonetheless, having the large contingent of Cardiff 'risk' fans voluntarily 'contained' on busses and arriving en masse in an agreed location was more preferable for the police than these fans travelling independently, in a completely unregulated fashion and materializing in smaller groups in unspecified locations in and around local town centres. In response to this dilemma, CCFC and SWP developed a pragmatic approach. The RAMs were officially recognized as a travel provider-allowing them access to tickets-but CCFC and SWP operated what they referred to as a 'drink not drunk' policy where they tolerated alcohol consumption on RAMs coaches. Thus, alcohol would be regularly and heavily consumed despite the fact that this was illegal. This adjustment of 'tolerance limits' was explicitly recognized by the SWP as a means of reducing the overall potential for 'disorder':

It's about an accepted tolerance level for their drink. We [the Police] know that they are going to drink. So are you going to be tolerant and say yes you can drink or do you say no you are not going to have a drink? [If you say no] perhaps they won't turn up, perhaps they will go into the city centre to meet up with somebody. Perhaps they will exchange blows. (SWP, FIO, WP)

To make the policy work, it was necessary for the SWP to seek agreement that host forces would adopt an equally pragmatic approach. Where the host force provided such tolerance, our field notes record that the RAMs actively demonstrated that they were not seeking to openly flaunt their contravention of the act. They achieved this by ensuring that each of their coaches (often in excess of 20) would stop just prior to their arrival in the host force area and all the alcohol on board would be stored out of sight:

We had one rule and that was when we got within ten miles or so of whichever ground we were travelling to, we would have to clear the bus compartment of any booze .... If it was in an area where the policing was relaxed it would mean hiding the drink in the storage areas under the bus. (Fan, GD)

On occasion, we even observed the host police stopping and boarding RAMs buses as they entered the force area. Our interviews with the relevant commanders allowed us to determine that, whilst such 'stop and search' was ostensibly to enforce this aspect of the act, they deliberately did not search the luggage compartments, even though they knew alcohol was stored there.

The act therefore created a potential 'objective' tension between the facilitation of fans to exercise identity consonant action (i.e. to drink on their way to football) and 
STOTT ET AL.

the role of the police as enforcers of the law (i.e. to stop them). However, our analysis suggests that the success of this 'relaxed' approach lay not just in the facilitation of fans by the police, but also in the way that fans reciprocated by 'self-regulating' and otherwise behaving in ways that allowed the police to quite literally 'act out' their role as enforcers of the law.

\section{Police legitimacy, fans' 'self-regulation' and compliance}

Our data therefore suggest that, where such 'facilitation and dialogue' policing occurred at away fixtures, it also engendered a perception of intergroup legitimacy among the RAMs, and, in doing so, reduced the potential for disorder via 'self-regulation' processes. In one case, our interview data with West Yorkshire Police (WYP) commanders showed that they held the view that the scale and intensity of a major incident of collective conflict involving Cardiff fans at a previous fixture under their jurisdiction were in part an outcome of overly aggressive police tactics. Some months prior to a subsequent fixture involving CCFC, the Senior WYP Commander adopted a programme of dialogue with representatives from the RAMs where his focus was upon facilitation. The RAMs' representatives conveyed the sense of intergroup legitimacy that subsequently developed:

It was the best meeting I ever had in any of the negotiations. Instead of saying what we could do for him, the first thing he said was 'what can we do for you', which was great and we sat down and discussed [things] like that and it was so successful. (Fan, GD)

In contrast to the earlier event, this fixture passed off without major incident. Our data from this event suggest that that was in part because of important moments of 'self-regulation' among the fans. Prior to the fixture, the WYP facilitated the RAMs access to a pub a short distance from the stadium. The coaches travelled to the pub without any coercion and, as such, were in a location far away from any opposition fans. After drinking heavily and for some time, Cardiff fans boarded their coaches to travel to the match. As they did so, the landlord communicated to the police that his karaoke machine had been stolen. Immediately, this information was passed to RAMs organizers and, a short time later, the undamaged karaoke machine was returned and the transgressing fan was severely 'rebuked' by other RAMs, who, in turn, provided an apology and $£ 40.00$ in cash to the landlord by way of compensation. As a consequence, the police took no further action.

Such policing contexts also coincided with examples of RAMs forgoing the potential for engaging in intergroup conflict even in the face of extreme provocation from other fan groups. For example, CCFC played against Leeds United at Elland Road in 2005a fixture understood by many as one of the highest-risk fixtures in England and Wales. Again adopting the 'facilitation and dialogue approach', West Yorkshire Police met the RAMs' coaches at a rendezvous point at a nearby motorway service station. On the basis of interview data with the police commander, we were able to determine that the WYP deliberately did not search the luggage spaces for alcohol before escorting them to the stadium. Following the match, police requested that the Cardiff fans remained in the stadium. However, approximately 300 Leeds United fans congregated outside and attempted to force their way through a police cordon to confront the Cardiff fans. It took the West Yorkshire Police approximately 45 minutes to disperse the Leeds fans 
with batons and horse charges but, throughout this period, the Cardiff fans did not become agitated and complied with police instructions. Contemporaneous interview data from RAMs organizers indicate that Cardiff fans consciously decided not to seek to break out from the stadium to become involved in the disorder they knew to be going on outside. When the Cardiff fans were finally allowed to leave the stadium, the police commander chose not to prevent a RAMs mini-bus from driving around the car park and delivering to each coach a 'slab' of beer cans. On the basis of our interview with the commander, we were able to ascertain that this 'turning of the eye' by the police was intended as a symbolic 'reward' for the fans' good behaviour and to help to avoid any of the coaches stopping on the way back to Cardiff to stock up on alcohol.

\section{Police illegitimacy and the presence of collective conflict}

Given Cardiff fans' historical involvement in 'disorder', the entire contingent of RAMs coaches would often be classified by host police forces as posing a serious threat to public order. For example, prior to a Cardiff fixture in 2005, a Chief Inspector in the South Yorkshire Police described the 'risk' the RAMs posed in an email to his planning team:

In the Cardiff City fan base [there are] a large number of Category A and B fans, who can be difficult to police and also on occasions involve themselves in disorder. This group traditionally, although not exclusively, has been embedded in the Valley RAMs Supporters Club which generally travel by coach. (SYP fixture policy document, Insp. MS)

Our field notes record that this level of perceived threat would, at times, lead some forces to avoid dialogue and rely upon 'deterrence' through the deployment of large numbers of police. Their primary tactic would be to control the movement of the entire contingent of RAMs by containing them through threat of arrest and use of force. ${ }^{3}$ In addition, these forces would tend to conduct extensive searches of the coaches for alcohol and impose punishments if any were found. ${ }^{4}$ Our interviews suggested that this deterrence approach, in turn, fed into perceptions among the RAMs of the illegitimacy of policing:

I think we get treated like shit [when the RAMs travel] away. You know we got every single restriction against us when we arrive at away teams. When we arrive at their towns and their grounds we are met by police in riot gear. They are all like Robocop, very physical towards us, and basically looking for us to cause trouble. [But] they kind of provoke us, so yeah away [policing is] definitely much worse [than policing at Cardiff]. (RAM, NBY)

The implications of deterrence approaches were evident during one incident of collective conflict involving Cardiff fans during and after a fixture under the jurisdiction of a police force from central England. Prior to the fixture, our interview with SWP recorded that, despite requests to do so, the host force had not sought any intelligence or cooperation from them. The host force then deployed approximately 375 police officers in an attempt to control any potential for conflict. The event passed off without

\footnotetext{
${ }^{3}$ Such containment, sometimes referred to as 'kettling', is achieved on the basis that anyone attempting to leave the containment is acting in a manner that is likely to cause a 'breach of the peace' and can therefore be arrested.

${ }^{4}$ However, it was unusual for these forces to find alcohol, as the lack of cooperation from the police usually influenced the RAMs to leave their alcohol in a hedge just before arriving in the host county and pick it up again on the return journey.
} 
noticeable incident until the half-time interval, at which point, large numbers of Cardiff fans moved into the concourse area under their stand. Although the host force had tried to impose restrictions on the sale of alcohol to CCFC fans, beer was initially being served. Shortly after the interval began, staff closed the shutters on the refreshment stalls. Some Cardiff supporters tried to re-open them and chanted 'we want beer'. The staff radioed for assistance and uniformed police officers and club stewards already in the vicinity responded. There was a short struggle between police and a group adjacent to the bar, following which, according to our observations, the situation began to calm. However, at this point, a large group of police in full 'protective equipment' (i.e. helmets, batons and shields) and some with dogs entered the concourse and pushed into the crowd, some officers striking out with batons. Large numbers of Cardiff fans then began to push back at police lines. The police forced supporters from the concourse back up the stairs and out onto the lower terrace of the stand, entered the seated terrace area and again struck supporters with batons. As consequence of the crushing caused by police intervention, some fans entered the pitch and the referee consequently delayed the kick-off for the second half. Confrontations continued between Cardiff supporters and the police for about 15 minutes. After the match had finished, there was further conflict between Cardiff fans, home fans and police in the vicinity immediately outside the stadium.

Fan accounts of the conflict described the incidents outside the refreshment kiosk just prior to police intervention as largely legitimate and posing no serious threat of violence or 'disorder'. For example, one 15-year-old girl, who was queuing at the kiosk, explained that:

At half time my friend and I were in the kiosk queue waiting to be served when the Cardiff fans started to sing childish banter of 'we want beer'. The fans also held up the shutters but this again was harmless and they were only having a laugh. (Fan, LM)

Others described the intervention by the police as indiscriminately violent and unwarranted:

I saw a woman hit with a riot baton. I saw my son whose only crime was that he went to the toilet at half time repeatedly hit over the head and across the legs by the police. Because of the number of police and supporters he could not move anywhere. He had to just take an unnecessary and unprovoked attack from the police, the people who are supposedly there to ensure the safety of well-behaved supporters like my son and myself. (Fan, BK)

For other fans, physical action came to be seen as a legitimate means of self-protection under these circumstances:

By this time I was stuck in the middle and there was no way possible for me and other innocent people to escape back to a safe area. The police ordered everyone back by threatening them with their batons. I tried to explain to a policeman that I was trying to get out of the way and he told me to fuck off back or he would hit me with his baton. Everyone was pushed back against the wall together which obviously frustrated a lot of fans and was the reason for them pushing forward as the ones at the back were probably having their backs squashed against the shelf that was on the wall. (Fan, BK)

Thus, in contrast to patterns of declining intergroup conflict between police and CCFCfans elsewhere, this incident demonstrates that the potential for intergroup conflict remained. Moreover, data suggest that this conflict coincided with the use of a deterrence-based policing approach that relied upon forceful and relatively indiscriminate forms of police interventions 
combined with an absence of facilitation and dialogue. In this context, data again suggest that there emerged a sense of illegitimacy among fans in their relationship with the police and a perception of the legitimacy of confrontational action against police.

\section{Challenges for sustaining peaceful social relations}

The lingering potential for intergroup conflict between fans of CCFC and the police raises the question of whether and how changes away from intergroup conflict can be sustained, particularly in the longer term. On the one hand, it is evident that the 'facilitation and dialogue' approach was not only understood as legitimate by fans, but that these perceptions of legitimacy were framed within an historical social context of alternative policing approaches. As one RAMs member noted:

South Yorkshire was bad at one time. You know the trouble we have had up in Sheffield and what have you, over the years. But they have come around now. [South Yorkshire Police] are being overly nice, they are giving us pubs for the boys to have a drink in. They are learning. (Fan, KT)

On the other hand, police adopting the facilitation and dialogue approach not only engaged in implicit comparison with deterrence-based alternatives, but defended the approach in the face of such comparisons:

It's not a weak system of policing though. I mean we don't take a back step. If you see when there is disorder we are firm and very affective. (SWP, Supt. 01)

Thus, both fans and police characterized the change away from conflictual intergroup relations as being embedded in sets of competing alternatives (i.e. deterrence versus facilitation, policing as legitimate versus illegitimate) that can exist in specific crowd events. This was recognized by the RAMs themselves, some of whom described how forms of policing they saw as legitimate were not simply those that did not use forceful tactics, but those that balanced facilitation against the use of force. In other words, the perception of intergroup legitimacy was a matter of the proportionality of the police response as perceived by fans themselves. Fans remained of the view that deterrence policing could be counterproductive, but suggested that, in the overall context of policing seen as fair and proportionate, firm action against transgressors would not only be tolerated, but actually welcomed:

Some scum bags need to be treated badly. But when and where do you draw the line. I have thought sometimes, when they have been treating us too nicely, thinking fucking hell they had better keep this in check before they get too powerful. It's a balance you know. (Fan, GD)

\section{Discussion}

This paper had two central aims. The first was to explore the processes that can account for the presence or absence of 'collective disorder' in domestic football-related crowd conflict. The second was to address how theory of these underlying processes might usefully inform policy debates concerning reduction in the cost of policing football 'hooliganism' in England and Wales. To achieve these, we focused on one of the most problematic fan groups in the United Kingdom, collecting data from them, and a range of other groups with whom they interacted, across a series of events. Our analysis suggests a general decline in the levels of collective conflict involving Cardiff fans across 
a period of five seasons, particularly at Ninian Park. But, throughout this period of decline, our data also indicated the sporadic re-emergence of 'major incidents' of 'disorder', primarily at away fixtures.

Leaving aside debates about the origins of 'hooligan' culture, we sought to analyse the phenomena from the perspective of social identity and procedural justice-based models. Our analysis suggests that the decline in collective conflict at and around Ninian Park occurred in parallel with a move away from a 'deterrence' towards a 'dialogue and facilitation'-based policing approach by the local police force (Holgersson and Knutsson 2011; Stott 2011; Gorringe et al. 2010). Our analysis suggests specific intergroup relationships between police and CCFC fans grew from this change that then impacted upon both the inter and intra-group dynamics of crowd events.

On the one hand, our evidence suggests that there were increasing levels of perceived legitimacy in the fans' relationships with the authorities. On the other, fans appear to have 'self-regulated' in situations of potential intergroup conflict. Our data also suggest that 'hooligans' were correspondingly disempowered, apparently as a direct result of their growing inability to influence the wider body of fans. This change in the internal dynamics of the fan group appears to have impacted back upon the intergroup context. The increasing trust and 'compliance', quality of intelligence along with the lowering levels of conflict over time allowed the SWP to withdraw resources from fixtures they had historically policed heavily. Within two seasons of implementing the model, 'significant' incidents of 'disorder' all but disappeared from home fixtures and policing costs had reduced by 50 per cent.

Further evidence supporting our contentions regarding the centrality of intergroup interaction between police and fans is reinforced through our analysis of fixtures away from Ninian Park. In these contexts, there was further evidence of perceptions of police legitimacy and important episodes of 'self-regulation' that coincided with policing approaches based upon 'dialogue and facilitation'. These episodes of 'self-regulation', in turn, appear to have helped maintain trust and resulted in the psychological and physical marginalization of those seeking conflict. These processes coincided with a reduction in 'hooliganism' compared to previous Cardiff fixtures-often at the same stadiums-enabling resource and therefore cost reduction for that host force at subsequent fixtures.

Almost polar-opposite group-level processes were apparent in situations in which major collective conflict did take place. Sporadic incidents occurred in a circumstance in which the host police force was apparently less capable of engaging in dialogue and more reliant on a 'deterrence' approach to public order policing. Such policing coincided with perceptions of police illegitimacy and the appropriateness of confrontation. In this sense, our data reinforces the view that the 'deterrence' policing approach can be counterproductive, as, not only was such an approach apparent in the context of a major escalation of collective conflict, but it was also potentially one of its primary causes (Stott and Drury 2000).

The processes and relationships between police legitimacy, intergroup dynamics and 'self-regulation' that we have detailed in this paper correspond with existing ESIM research on how public 'disorder' in the context of international football tournaments is created (Stott and Reicher 1998b; Stott et al. 2001) and can be avoided (Reicher 2004; 2007; Stott et al. 2007; 2008a). But, until now, there has been little testing of ESIM's 'conflict reduction' approach in any domestic football context. The small body of ESIM 
research that does exist within this domain focuses on developing models of effective police practice and exploring the relationships between police understanding of crowds and their strategic and tactical responses.

The existing work suggests the importance of a consent-based approach (Alderson 1984; Hough 2007) to the policing of football (Stott et al. 2008b). Moreover, is suggests that an understanding of ESIM crowd processes are under-utilized by the police in domestic football contexts, which is leading to missed opportunities for conflict reduction in the longer term (Hoggett and Stott 2010a; 2010b). The current study reinforces these contentions but adds evidence of the underlying social psychological processes that are potentially mediating the relationships between policing and public order outcomes in domestic football. The processes we have identified here are consistent with the theoretical principles of both ESIM and PJT and therefore demonstrate their potential relevance in understanding how to develop a strategy for reducing the likelihood of 'disorder' in domestic league contexts over the longer term (see also HMIC 2009).

In this respect, both ESIM and PJT approaches provide a consistent and far-reaching case that the route to police legitimacy and therefore conflict reduction during domestic football crowd events resides in developing police capability to act proportionately through 'dialogue'-based approaches. Our data are consistent with the idea that this is because, in so doing, they are (1) more likely to maximize normative consent within the crowd and (2) maintain or even build institutional legitimacy for the police that, in turn, increases fans' commitment to the rule of law (Hough et al. 2010). In this respect, we suggest that the evidence we present here supports the assertion that 'normative compliance is economically more viable, and is more stable over time than instrumental compliance which.... carries a growingly unaffordable social and fiscal cost' (Hough et al. 2010: 205).

There are, of course, some important limitations to this study. First and foremost, our evidence is drawn from one fan group and therefore there are serious questions about the generality of these processes. The RAMs are relatively unique in terms of their identity, as are the social and cultural conditions of the geographical location from where they originate. The processes we have identified may therefore be unique to them. Moreover, our analysis is primarily qualitative and lacks any statistical test of the relationships our analysis suggests may be playing a determining role. However, we are, with this study, merely seeking to explore the potential relevance of a social identity and procedural justice-based analysis in the domain of domestic football-related disorder. As such, this study can only ever act as a precursor to further research and should not be seen as a conclusive case that the factors that we have identified are some kind of panacea for football 'hooliganism'.

We must stress that we are not seeking to deny the important role that the local situation may have played in affecting the processes we have identified. For example, many of the initiatives developed by SWP were an outcome of demands placed upon them by the fact that Cardiff became to host city for high-profile football fixtures-such as the FA Cup Final-during the redevelopment of the English National Stadium at Wembley. Also, the football club was promoted to the second tier of the English Football League in the 2002/03 season and then remained there for the duration of our research. But, despite this relative stability in league position, the club was seeking to build and then move to its new stadium-a move that finally took place in 2009. Continued widespread 'hooliganism' among the fans throughout the period of our research would have 
STOTT ET AL.

severely undermined the ability of the club to attract the necessary political support and investment needed to make their new home a possibility. This clearly would have been a factor framing the processes we have described.

But these weaknesses do not undermine the ability of our data to account for the variability in collective disorder involving Cardiff fans in a manner that is more powerful and parsimonious than alternative explanations. Moreover, our analysis should not be seen in isolation from the now substantive ESIM and procedural justice literature. Our evidence is consistent with the idea that 'compliance' in this context was an outcome of the way dynamic intergroup interactions feed into the 'identity information' that fans used to understand themselves and their social relationships which, in turn, governed the form of their collective action. In this respect, our analysis suggests that the route to conflict reduction in domestic football-at least in England and Wales-is not merely through 'deterrence' policing based upon 'instrumental' models of social compliance (e.g. Harcourt 2001). Rather, our research suggests the relevance to 'public order' of Tyler's 'process based' policing model, which proposes that reductions in criminality reside in generating policing responses that are perceived as legitimate (Sunshine and Tyler 2003; Hough et al. 2010).

Furthermore, what we also demonstrate with this analysis is the historical dimension to these social psychological processes and their relevance to understanding 'hooliganism' within domestic competitions. Since the processes we have identified occurred across multiple events and locations, our analysis also points towards the need for a more integrated approach to the policing of high-risk fan groups; a 'dialogue and facilitation' approach will only be effective if both visiting and host forces adopt it and do so across the longer term. In other words, a piecemeal short-term approach to the policing of football, based primarily upon the use of force, may be the root cause of the enduring nature of the problem. This is so because such 'short-termism' prevents the management of the historical processes that can and would deliver longer-term conflict, and therefore cost, reduction.

\section{Funding}

This research was funded by the Untied Kingdom Football Policing Unit (UKFPU) and the Economic and Social Research Council (ESRC) Case Award PTA/033/2005/00044.

\section{REFERENCES}

Alderson, J. (1984), Law and Disorder. London: Hamish Hamilton.

Blader, S. and Tyler, T. R. (2009), 'Testing and Extending the Group Engagement Model: Linkages Between Social Identity, Procedural Justice, Economic Outcomes, and Extrarole Behaviour', Journal of Applied Psychology, 94: 445-64.

Burgess, R. G. (1982), Field Research: A Sourcebook and Field Manual. London: Allen and Unwin.

Davies, G. (2009), The Rise and Fall of the Cardiff City Valley RAMs. Cardiff: Abraham. Denzin, N. K. (1989), The Research Act. 3rd edn, Englewood Cliffs, NJ: Prentice Hall.

Drury, J. and Reicher, S. (2000), 'Collective Action and Psychological Change: The Emergence of New Social Identities', British Journal of Social Psychology, 39: 579-604. 
Drury, J. and Stotт, C. (2001), 'Bias as a Research Strategy in Participant Observation: The Case of Intergroup Conflict', Field Methods, 13: 47-67.

Drury, J., Stott, C. and Farsides, T. (2003), "The role of police perceptions and practices in the development of public disorder", Journal of Applied Social Psychology, 33: 480-500.

Frosdick, S. and Marsh, P. (2005), Football Hooliganism. Cullompton: Willan.

Glaser, B. G. and Strauss, A. L. (1967), The Discovery of Grounded Theory: Strategies for Qualitative Research. New York: Aldine.

Gorringe, H., Stott, C. and Rosie, M. (2010), 'HMIC Goes to Millbank', Police Professional, Issue 232.

Hammersley, M. and Atkinson, P. (1983), Ethnography: Principles in Practice. London: Tavistock.

Her Majesty's Inspectorate of Constabulary (HMIC) (2009), Adapting to Protest-Nurturing the British Model of Policing. .

Hoggett, J. and Stotт, C. (2010a), 'Crowd Psychology, Public Order Police Training and the Policing of Football Crowds', Policing: An International Journal of Police Strategies and Management, 33: 218-35.

Hoggett, J. and Stotт, C. (2010b), 'The Role of Crowd Theory in Determining the Use of Force in Public Order Policing', Policing and Society, 20: 223-36.

Holgersson, S. and Knutsson, J. (2011), 'Dialogue Policing:A Mean for Less Crowd Violence?', in T. D. Madensen and J. Knutsson, eds, Preventing Crowd Violence: Crime Prevention Studies. Boulder CO: Lynne Rienner Publishers.

Hough, M. (2007), 'Policing New Public Management and Legitimacy', in T. Tyler, ed., Legitimacy and Criminal Justice. New York: Russell Sage Foundation.

Hough, M., Jackson, J., Bradford, B., Quinton, P. and Myhill, P. (2010), 'Procedural Justice, Trust, and Institutional Legitimacy', Policing, 4: 203-10.

Jackson, J., Bradford, B., Hough, M. and Murray, K. H. (in press), 'Compliance with the Law and Policing by Consent:Notes on Police and Legal Legitimacy', in A. Crawford and A. Hucklesby, eds, Legitimacy and Compliance in Criminal Justice. London: Routledge.

James, M. and Pearson, G. (2006), 'Football Banning Orders: Analysing Their Use in Court', Journal of Criminal Law, 70: 509-30.

Lewin, K. (1951), Field Theory in Social Science. New York: Harper and Row.

Murray, K. (2010), 'Police Legitimacy and Public Protest', Edinburgh, School of Law Working Paper Series, No. 2010/36, University of Edinburgh.

Pearson, G. (2011), An Ethnography of English Football Fans 1995-2010: Cans, Cops and Carnival. Manchester: Manchester University Press.

Pearson, G. and Sale, A. (2011), 'On the Lash: Revisiting the Effectiveness of Alcohol Controls at Football Matches', Policing and Society, 21: 1-17.

Reicher, S. (1996), 'The Battle of Westminster: Developing the Social Identity Model of Crowd Behaviour in Order to Explain the Initiation and Development of Collective Conflict', European Journal of Social Psychology, 26: 115-34.

Reicher, S., Stott, C., Cronin, P. and Adang, O. (2004), 'An Integrated Approach to Crowd Psychology and Public Order Policing', Policing, 27: 558-72.

Reicher, S., Stott, C., Drury, J., Adang, O., Cronin, P. and Livingstone, A. (2007), 'Knowledge Based Public Order Policing: Principles and Practice', Policing: A Journal of Policy and Practice, 1: 403-15. 
STOTT ET AL.

Schreiber, M. and Stott, C. 'Policing International Football Tournaments and the CrossCultural Relevance of the Social Identity Approach to Crowd Behaviour', Police Practise and Research.

Smith, J. A. and Osborn, M. (2003), (in press), 'Interpretative Phenomenological Analysis', in J. A. Smith, ed., Qualitative Psychology: A Practical Guide to Methods.. London: Sage.

Stotт, C. (2011), 'Crowd Dynamics and Public Order Policing', in T. D. Madensen, Knutssontjlmm tjlJ., eds, Preventing Crowd Violence. London and Boulder, CO: Lynne Rienner.

Stott, C. and Pearson, G. (2006), 'Football Banning Orders, Proportionality and Public Order', Howard Journal of Criminal Justice, 45: 241-54.

Stott, C. and Pearson, G. (2007), Football Hooliganism: Policing and the War on the English Disease. London: Pennant Books.

Stott, C. and Reicher, S. (1998a), 'Crowd Action as Intergroup Process: Introducing the Police Perspective', European Journal of Social Psychology, 26: 509-29.

Stotт, C. and Reicher, S. (1998b), 'How Conflict Escalates: The Intergroup Dynamics of Collective Football Crowd Violence', Sociology, 32: 353-77.

Stott, C. and Schreiber, M. (In press), Policing international football tournaments and the cross-cultural relevance of the social identity approach to crowd behavior. Police Practice and Research: An International Journal.

Stott, C., Livingstone, A. and Hoggett, J. (2008b), 'Policing Football Crowds in England and Wales: A Model of Good Practice?', Policing and Society, 18: 1-24.

Stott, C., Adang, O., Livingstone, A. and Schrieber, M. (2007), 'Variability in the Collective Behaviour of England Fans at Euro 2004: Hooliganism, Public Order Policing and Social Change', European Journal of Social Psychology, 37: 75-100.

Stott, C., Adang, O., Livingstone, A. and Schreiber, M. (2008a), 'Tackling Football Hooliganism: A Quantitative Study of Public Order, Policing and Crowd Psychology', Psychology, Public Policy, and Law, 14: 115-41.

Stott, C., Hutchinson, P. and Drury, J. (2001), 'Hooligans Abroad? Inter-Group Dynamics, Social Identity and Participation in Collective Disorder at the 1998 World Cup Finals', British Journal of Social Psychology, 40: 359-84.

Sтотт, C. J. (2003), 'Police Expectations and the Control of English Soccer Fans at "Euro2000", Policing: An International Journal of Police Strategies and Management, 26: 640-55.

Stott, C. J. and Drury, J. (2000), 'Crowds, Context and Identity: Dynamic Categorization Processes in the "Poll Tax Riot", Human Relations, 53: 247-73.

Sunshine, J. and Tyler, T. R. (2003), 'The Role of Procedural Justice and Legitimacy in Public Support for Policing', Law and Society Review, 37: 513-48.

Turner, J. C., Oakes, P. J., Haslam, S. A. and McGarty, C. (1994), 'Self and Collective: Cognition and Social Context', Personality and Social Psychology Bulletin, 20: 454-63.

Tyler, T. R. (1990), Why People Obey the Law. New Haven: Yale University Press.

Tyler, T. R. (2003), 'Procedural Justice, Legitimacy and the Effective Rule of Law', in

Tonry M., ed., Crime and Justice: A Review of Research, 30, 431-505. Chicago: University of Chicago Press.

Tyler, T. R. (2007), Legitimacy and Criminal Justice. New York: Russell Sage Foundation.

Tyler, T. R. and Blader, S. L. (2000), Cooperation in Groups.. Philadelphia, PA: Psychology Press.

Tyler, T. R. and Blader, S. L. (2001), 'Identity and Cooperative Behaviour in Groups', Group Process and Intergroup Relations, 4: 207-26. 
Tyler, T. R. and Blader, S. L. (2003), 'The Group Engagement Model: Procedural Justice, Social Identity, and Cooperative Behaviour', Personality and Social Psychology Review, 7: 349-61.

Tyler, T. R. and Huo, Y. J. (2002), Trust in the Law: Encouraging Public Cooperation with the Police Courts.New York: Russell Sage Foundation.

Whyte, W. F. (1994), Participant Observer: An Autobiography. Ithaca, NY: ILR Press. 